\title{
Primary hyperparathyroidism in developing world: a systematic review on the changing clinical profile of the disease
}

Sanjay Kumar Yadav'

https://orcid. org/0000-0002-0682-4970

Goonj Johri²

https://orcid. org/0000-0002-3699-7338

Raouef Ahmed Bichoo²

https://orcid.org/0000-0002-9386-403X

Chandan Kumar $\mathrm{Jha}^{3}$

https://orcid.org/0000-0003-0968-3269

Ronald Kintu-Luwaga ${ }^{4}$

https://orcid. org/0000-0001-7273-1978

Saroj Kanta Mishra ${ }^{2}$

https://orcid.org/0000-0003-0635-3897

\begin{abstract}
While the developed world is focusing on laying guidelines for selecting out cases of Asymptomatic primary hyperparathyroidism (PHPT) for surgical intervention and promoting minimal access surgery, the developing world is observing a change in disease spectrum from advanced symptomatic to lesser degree of symptomatic disease and not many with associated Vitamin D deficiency. Few studies from the developing countries of the world have focused on the changing clinical spectrum of PHPT. Objective of this study is to review the changing profile of PHPT in developing world. A systematic literature search was done in December 2017 focussing on publications from the developing world. All studies pertaining to the epidemiology of PHPT published after $1^{\text {st }}$ January 2000 and published in English language were included for analysis. Most of the studies published from developing countries report a predominance of symptomatic disease (79.6\% of all included patients) with musculoskeletal disease present in the majority of patients $(52.9 \%)$. The combined mean serum total calcium (11.9 $\pm 1.4 \mathrm{mg} / \mathrm{dL})$, serum PTH $(668.6 \pm 539 \mathrm{pg} / \mathrm{mL})$, serum alkaline phoshpatase $(619 \pm 826.9 \mathrm{IU} / \mathrm{L})$ and weight of excised parathyroid glands $(4.4 \pm 3.8$ grams) are much higher than those reported from the western studies. Despite this, we found that there is a distinct trend towards a milder form of disease presentation and biochemical profile noticeable in more recent times. Although there is a striking difference in all aspects of PHPT disease epidemiology, clinical presentation and biochemical profile of developing and developed countries, there is a distinct trend towards a milder form of disease presentation and biochemical profile in more recent times. Arch Endocrinol Metab. 2020;64(2):105-10
\end{abstract}

Keywords

Primary hyperparathyroidism; developing country; symptomatic PHPT; clinical spectrum of PHPT
1 Department of Breast and Endocrine Surgery, Kalinga Institute of Medical Sciences, Bhubaneswar, Odisha, India ${ }^{2}$ Department of Endocrine Surgery, Sanjay Gandhi Postgraduate Institute of Medical Sciences, Raebareli Road, Lucknow, India ${ }^{3}$ Department of General Surgery, AllMS, Patna, India

${ }^{4}$ Mulago National Referral

Hospital, Kampala, Uganda
Correspondence to: Chandan Kumar Jha Department of General Surgery All India Institute of Medical Sciences, Patna - 801507, India cjhadmch@gmail.com

Received on Feb/7/2019 Accepted on June/26/2019

DOI: $10.20945 / 2359-3997000000211$

\section{INTRODUCTION}

$\mathrm{P}$ rimary hyperparathyroidism (PHPT) emerged as a distinct clinical entity in 1920-1930. Since then the disease epidemiology and clinical-investigative protocols have witnessed a dramatic change. For the first 40 years after its recognition, the disease symptomatology was classically described as "stones, bones, moans, and groans". However, the advent of a multichannel biochemical screening test in the early 1970s led to a clinical revolution in the diagnosis of
PHPT with increased incidence by four to five- fold and appearance of the asymptomatic era of PHPT in developed countries (1).

Numerous publications between the years 1984 to 2010 from around the developing countries provided contrasting views on disease epidemiology and spectrum of clinical presentation (2-5). While the developed world focused on laying guidelines for filtering out cases of asymptomatic PHPT for surgical intervention and promoting minimal access surgery with the aid of 
newer diagnostic and localization tools, the developing world was observing a change in disease spectrum from advanced symptomatic to lesser degree of symptomatic disease and a reduction in incidence of associated Vitamin D deficiency. Some authors from developing countries have focused on the changing clinical spectrum of PHPT (6-10) and suggested that the trajectory of the change is similar to what was observed in developed countries a few decades earlier. We observed these dramatic changes in disease epidemiology and sought to review and address the question that whether the epidemiology of this disease continues to differ from the developed countries?

\section{MATERIALS AND METHODS}

A systematic literature search on PubMed/Medline, Embase, Science Citation Index Expanded (SciSearch), Scopus and Cochrane Databases was done in December 2017 using keywords ["Primary hyperparathyroidism" AND "C"], where $C$ is the name of a developing country according to WHO developing country stratification. The inclusion criteria were as follows: studies pertaining to the epidemiology of PHPT published after $1^{\text {st }}$ January 2000 and studies published in English language. Case reports, case series with less than ten subjects and studies on PHPT which didn't report on the clinical/surgical/ biochemical profile were excluded.
The study title, year of publication, sample size, patient demographics, disease characteristics, intervention (surgery vs medical management) and mean values of biochemical parameters [e.g. serum total calcium, parathormone (PTH), Vitamin D $[25(\mathrm{OH})$ Vitamin-D], creatinine, and phosphate were extracted from each study. Wherever required, the biochemical parameters were converted into thestandard units for the ease of comparison between studies.

\section{RESULTS}

Developing countries lag behind developed countries in the number of publications. Majority of publications from developing countries are from India, China, Brazil, and Turkey. Publications from other developing countries are mostly case reports, small case series, and retrospective case series. These publications lack uniformity in the presentation, analysis, interpretation of data, and the specific information needed for a metaanalysis and appropriate statistical tests. The result of our search identified 115 publications from developing countries. After the exclusion of unrelated studies, case reports, and small case series, seventeen publications were eligible for review. All seventeen studies were observational in design and the details of the study are described in Table 1.

Table 1. Published studies from developing countries

\begin{tabular}{|c|c|c|c|c|c|}
\hline S. No. & Author & Country & Period of study & No. of patients & Notable findings \\
\hline 1 & Younes NA et al. (11) & Jordan & $1990-2002$ & 40 & $70 \%$ had skeletal disease \\
\hline 2 & Ohe MN et al. (7) & Brazil & 1985-2002 & 104 & $53 \%$ symptomatic \\
\hline 3 & Malabu UH et al. (12) & Saudi Arabia & $2000-2006$ & 46 & $76 \%$ symptomatic \\
\hline 4 & Prasarttong-0soth $\mathrm{P}$ et al. (13) & Thailand & $1997-2007$ & 45 & $97.8 \%$ symptomatic \\
\hline 5 & Zhao L et al. (14) & China & $2000-2010$ & 249 & $61.4 \%$ symtomaic \\
\hline 6 & Paruk IM et al. (15) & South Africa & 2003-2009 & 28 & $92.9 \%$ symptomatic \\
\hline 7 & Eufrazino et al. (16) & Brazil & $2007-2008$ & 33 & $90 \%$ symtomatic but clasicalsymtoms only in $18.2 \%$ \\
\hline 8 & Shah VN et al. (17) & India & $1990-2010$ & 202 & $99.1 \%$ symtomatic \\
\hline 9 & Usta A et al. (18) & Turkey & 1993-2013 & 190 & $72.0 \%$ symtomatic \\
\hline 10 & Jha S et al. (19) & India & $1994-2015$ & 110 & $100 \%$ symtomatic \\
\hline 11 & Bhadada et al. (20) & India & 2005-2015 & 464 & $95 \%$ symtomatic \\
\hline 12 & Ahsan T et al. (21) & Pakistan & 2004-2014 & 25 & $96 \%$ symptomatic \\
\hline 13 & Yadav SK et al. (10) & India & $1990-2016$ & 333 & $69 \%$ had musculoskeletal symtoms \\
\hline 14 & Bahrami A et al. (22) & Iran & 1985-2002 & 62 & $100 \%$ symptomatic \\
\hline 15 & Bandeira F (23) & Brazil & Not reorted & 90 & $57 \%$ symtomatic \\
\hline 16 & Bandeira F (24) & Brazil & $2000-2006$ & 49 & $49 \%$ symtomatic \\
\hline 17 & Bandeira FA (25) & Brazil & $2000-2005$ & 64 & $61 \%$ had skeletal or/and renal disease \\
\hline
\end{tabular}




\section{Demographics}

Studies from South Africa (15) and Brazil (7) reported the mean age of presentation to be similar to that in the developed countries, although the vitamin $\mathrm{D}$ status of these patients was not reported. Studies from India, China, Pakistan, Iran and Turkey have reported median age of PHPT patients to be younger. Another interesting finding pertaining to the age of presentation was revealed in three Brazilian studies where the authors found that symptomatic patients presented at a much younger age than the asymptomatic ones (23-25). Seven studies, which overall included 1201 patients, reported on the vitamin $\mathrm{D}$ status of the patients (Table 2). The cumulative mean value of vitamin $\mathrm{D}$ for these patients is $22.0 \pm 22.6 \mathrm{ng} / \mathrm{mL}$, which falls into the category of 'insufficient viamin D level'.

\section{Clinical presentation}

Symptomatic disease is still the most common form of presentation in developing countriesand $79.6 \%$ of all included patients were symptomatic (Tables 1 and 3). Musculoskeletal (52.9\%) and renal disease $(34.9 \%)$ were the most common reasons for
presentation.It is hard to estimate the presence of neuropsychiatric disease in PHPT because they are rarely the presenting feature and may not be often recognized. This is manifested from our review as well, because only a few of the included studies reported the presence of neuropsychiatric disease in their patient cohort. Overall clinical presentation is summarised in Table 3.

\section{Biochemical severity}

Table 2 summarises the biochemical severity of PHPT in developing countries. As compared to developed nations, these patients presented with higher mean total serum calcium and PTH level. Mean total

Table 3. Overall clinical presentation in developing countries

\begin{tabular}{lccc}
\hline Feature & $\begin{array}{c}\text { Number of } \\
\text { studies } \\
\text { reporting } \\
\text { the feature }\end{array}$ & $\begin{array}{c}\text { Total number } \\
\text { of patients for } \\
\text { which data } \\
\text { available }\end{array}$ & $\begin{array}{c}\text { Total number } \\
\text { of patient } \\
\text { having the } \\
\text { feature (\%) }\end{array}$ \\
\hline Symptomatic & 17 & 2134 & $1699(79.6)$ \\
Musculoskeletal disease & 16 & 2030 & $1073(52.9)$ \\
Renal disease & 16 & 2030 & $709(34.9)$ \\
Gastrointestinal disease & 16 & 2030 & $211(10.4)$ \\
Neuropsychiatric disease & 16 & 2030 & $182(08.9)$ \\
\hline
\end{tabular}

Table 2. Summary of biochemical parameters and gland weight in reviewed studies

\begin{tabular}{|c|c|c|c|c|c|c|}
\hline $\begin{array}{l}\text { S } \\
\text { No }\end{array}$ & Country & $\begin{array}{l}\text { Serum Total Calcium } \\
+ \text { SD (mg/dL) }\end{array}$ & $\begin{array}{c}\text { Serum PTH + SD } \\
(\mathrm{pg} / \mathrm{mL})\end{array}$ & $\begin{array}{c}\text { Serum alkaline } \\
\text { phosphatase + SD (IU/L) }\end{array}$ & $\begin{array}{l}\text { 25-OH Vitamin-D } \\
\text { + SD (ng/mL) }\end{array}$ & $\begin{array}{l}\text { Mean weight of the } \\
\text { gland + SD (Grams) }\end{array}$ \\
\hline 1 & Jordan (11) & $10.7 \pm 1.2$ & $438.2 \pm 398$ & $296.7 \pm 245.9$ & NA & NA \\
\hline 2 & Brazil (7) & $12.0 \pm 1.3$ & $450.5 \pm 376.6$ & N/A & N/A & NA \\
\hline 3 & Saudi Arabia (12) & $12.0 \pm 0.4$ & $440.0 \pm 60.6$ & $473 \pm 146$ & $14.3 \pm 3.4$ & NA \\
\hline 4 & Thailand (13) & $13.1(8.1-22)^{*}$ & $341(107-2490)^{*}$ & $449(35-3384)^{*}$ & $\mathrm{~N} / \mathrm{A}$ & NA \\
\hline 5 & China (14) & $11.7 \pm 1.4$ & $402.1(103.2-2700.6)^{*}$ & $112(50-1419.9)^{*}$ & $13.0(5.2-29.9)^{*}$ & $2.6+1.2$ \\
\hline 6 & South Africa (15) & $12.1 \pm 1.6$ & $340.9 \pm 420.3$ & $206.3 \pm 340.2$ & $\mathrm{~N} / \mathrm{A}$ & $2.6 \pm 1.9$ \\
\hline 7 & Brazil (16) & $10.6 \pm 1.3$ & $182.5 \pm 326.5$ & N/A & N/A & NA \\
\hline 8 & India (17) & $11.7 \pm 1.5$ & $740.2 \pm 669.2$ & $556.9 \pm 551.4$ & $25.0 \pm 46.7$ & $4.7 \pm 1.6$ \\
\hline 9 & Turkey (18) & $11.9(8.8-15.4)^{*}$ & $467(102-2240)^{*}$ & $362(64-685)^{\star}$ & $\mathrm{N} / \mathrm{A}$ & NA \\
\hline 10 & India (19) & NA & $957.9 \pm 245.4$ & NA & NA & NA \\
\hline 11 & India (20) & $11.9 \pm 1.6$ & $752.4 \pm 735.2$ & $653 \pm 1180$ & $22.9 \pm 25.1$ & $5.6 \pm 6.5$ \\
\hline 12 & Pakistan (21) & $11.2 \pm 1.6$ & $879.5 \pm 793.5$ & $673.5 \pm 729.6$ & $16.3 \pm 14.3$ & NA \\
\hline 13 & India (10) & $12.7 \pm 1.6$ & $715.9 \pm 671.1$ & $699.7 \pm 725.7$ & $20.7 \pm 15.2$ & 3.6 \\
\hline 14 & Iran (22) & $11.2(9.3-15.6)^{\star}$ & $184 \pm 41(76-1300)$ & $657 \pm 116(84-3150)$ & NA & NA \\
\hline 15 & Brazil (23) & $12.0 \pm 0.5$ & $714.1 \pm 135.0$ & NA & NA & NA \\
\hline 16 & Brazil (24) & $11.3 \pm 0.7$ & $292.2 \pm 179.4$ & NA & $20.8 \pm 8.9$ & NA \\
\hline 17 & Brazil (25) & $11.9 \pm 0.2$ & $289.7 \pm 205.4$ & NA & $21.4+2.4$ & $3.7+2.5$ \\
\hline
\end{tabular}

*Mean values not reported in the study, median values with range provided. 
serum calcium level of $10.6 \pm 0.6 \mathrm{mg} / \mathrm{dL}$, mean PTH level of $67.5(47.9-94.9) \mathrm{pg} / \mathrm{mL}$ and mean alkaline phosphatase (ALP) level of 75 (62-92) IU/L was reported from USA (26). In contrast, all studies from developing countries except two (15 \& 31) have reported mean serum calcium above $11 \mathrm{mg} / \mathrm{dL}$, mean PTH level above $340 \mathrm{pg} / \mathrm{mL}$ (except 31, $34 \& 35$; all Brazilian studies) and mean ALP level above $400 \mathrm{IU} / \mathrm{L}$ in most studies.

We calculated the combined mean values for serum total calcium, serum PTH and serum ALP level of all included studies (wherever reported) to get an overall picture of the disease severity. The combined mean values for serum total calcium $(11.9 \pm 1.4 \mathrm{mg} / \mathrm{dL})$, serum PTH $(668.6 \pm 539 \mathrm{pg} / \mathrm{mL})$ and serum ALP $(619 \pm 826.9 \mathrm{IU} / \mathrm{L})$ are very different from what has been reported from the west. Mean weight of excised adenoma is also high in developing countries $(4.4 \pm$ 3.8 grams).

\section{Changing epidemiology}

We could identify only five studies examining the changing disease pattern in developing countries, three from India, and one each from China and Brazil (Table 4). Shah and cols. analyzed data of 202 patients over two decades and divided into four different time periods, i.e. 1990 to 1994,1995 to 1999,2000 to 2004 and 2005 to 2010 (17). Although clinical presentations of PHPT (predominance of bone and stone symptoms) did not differ across different time periods and nonsignificant decrease in serum calcium levels at the time of diagnosis of PHPT was observed but a significant decline in the serum ALP level $(\mathrm{P}<0.01)$ was found in the last decade, however, PTH level was higher in the last decade $(\mathrm{P}<0.05)$.Jha and cols. reported that although clinical severity of the disease has decreased significantly, biochemical abnormalities of high PTH and ALP are still the same (19). Yadav and cols. grouped the PHPT patients into three subgroups based on the time span; 1990-1999, 2000-2009, 2010-2016, and clinical and biochemical parameters were compared (10). The clinical presentation in this study has evolved progressively with increase in older age group (35 vs 39 vs $43.85, \mathrm{p}<0.001)$, less patients with musculoskeletal symptoms ( 85.3 vs 76.8 vs $61 \%, \mathrm{p}=0.002)$ and less patients with severe bone disease (29.4 vs 10.7 vs $10.7 \%, \mathrm{p}=0.088)$. Biochemical parameters also showed a changing trend with a significant decrease in mean ALP level (1393 vs 965 vs $414.8 \mathrm{IU} / \mathrm{L}, \mathrm{p}<0.001$ ) and serum PTH (837.52 vs 812.89 vs $635.74 \mathrm{pg} / \mathrm{mL}, \mathrm{p}=$ $0.02)$. Ohe and cols. grouped 104 Brazilian patients into three groups, patients diagnosed from 1985-1989, 1990-1994, and 1995 to 2002 (7). Patients from the first group tended to be younger (mean $\pm \mathrm{SD}, 43.0 \pm$ 15 vs $55.1 \pm 14.4$ and $55.7 \pm 17.3$ years, respectively) and their mean serum calcium was significantly higher.

Table 4. Studies from developing countries examining the change in pattern of PHPT

\begin{tabular}{|c|c|c|}
\hline Study & Patient population & Findings \\
\hline Shah VN et al. (17) & $\begin{array}{l}202 \text { patients, divided into } 4 \text { time groups } \\
1990-1994(n=6) \\
1995-1999(n=22) \\
2000-2004(n=43) \\
2005-2010(n=131)\end{array}$ & $\begin{array}{l}\text { Clinical presentation did not change over different time periods; non-significant decrease } \\
\text { in serum calcium; significant decline in the serum alkaline phosphatase level in the last } \\
\text { decade. }\end{array}$ \\
\hline Jha S et al. (19) & $\begin{array}{l}110 \text { patients, divided into } 2 \text { time groups: } \\
\text { 1994-2007 }(n=51) \\
2007-2015(n=59)\end{array}$ & $\begin{array}{l}\text { Pathological fractures more common in earlier subgroup, bone pain was more common in } \\
\text { later subgroup; median PTH values were similar in two time groups }\end{array}$ \\
\hline Yadav SK et al. (10) & $\begin{array}{l}333 \text { patients divided into } 3 \text { time groups: } \\
\text { 1990-1999 }(n=34) \\
2000-2009(n=112) \\
2010-2016(n=187)\end{array}$ & $\begin{array}{l}\text { Progressive increase in age at presentation; decline in proportion of patients presenting } \\
\text { with musculoskeletal disease; decline in mean serum PTH and serum alkaline } \\
\text { phosphatase level }\end{array}$ \\
\hline Ohe MN et al. (7) & $\begin{array}{l}104 \text { patients divided into } 3 \text { subgroups } \\
1985-1989(n=9) \\
1990-1994(n=30) \\
1995-2002(n=65)\end{array}$ & $\begin{array}{l}\text { Patients from earlier subgroup were significantly younger and had significantly higher } \\
\text { serum calcium values }\end{array}$ \\
\hline Zhao L et al. (14) & $\begin{array}{l}249 \text { patients presenting between 2000-2010; } \\
\text { Compared symtomatic and asymtomatic PHPT }\end{array}$ & $\begin{array}{l}\text { The overall features of PHPT not changed but asymptomatic presentation increased to } \\
50 \% \text { of all cases after 2007; symptomatic patients had significantly higher serum calcium, } \\
\text { PTH, alkaline phoshatase, and higher parathyroid gland weight. }\end{array}$ \\
\hline
\end{tabular}


Zhao and cols in their study of 249 Chinese PHPT patients reported that percentage of asymptomatic PHPT has increased from $21 \%$ in $2000-2006$ to $42.4 \%$ to $52.5 \%$ in $2007-2010$ (14).

\section{DISCUSSION}

The presentation of PHPT has changed from symptomatic to an asymptomatic disease in developed countries (1). However, there is a striking difference in all aspects of PHPT disease epidemiology, clinical presentation and biochemical profile of patients from developing countries when compared to profile of patients from developed countries, but the clinical and biochemical severity is decreasing and is somewhat similar to observations on western patients reported during the1980s and 90s (27-29). One of the most interesting findings from this review pertains to the age of presentation. Patients of from developing Asian countries seem to present at a younger age, with a difference of about 15-20 years. The exact pathogenesis of this young age of presentation has not been clearly established, but the widespread prevalence of vitamin $\mathrm{D}$ deficiency in these countries, which has been linked with parathyroid adenoma growth, may be playing its part (27). Another theory is increased awareness in western countries (26) along with routine biochemical screeningbut only increased awareness can not explain the drastically opposite presentation of PHPT in developing countries. The cause of this type of presentation must be multifactorial like patient awareness, physician awareness, health infrastructure and nutrition.

Delay in diagnosis incurs high healthcare cost in the form of morbidities associated with PHPT. Education of general public and training of health care personnel can lead to early identification and management leading to patient benefit. As the awareness among general population and physicians is increasingthe diagnosis of PHPT is increasing in developing world. Increasing number of specialist endocrine surgeons is increasing across the globe but it is still very less in developing countries (30).

With the trajectory being similar to west in the terms of clinical and biochemical profile with a temporal lag of one and half to two decades, it can be expected that in another two decades, a steady state would be achieved, as in western patients.

Author contributions, acknowledgement and cover letter:Sanjay Kumar Yadav, Chandan Kumar Jha- literature search, study design, data collection, data analysis, data interpretation, and writing of manuscrit. Goonj Johri, Saroj Kanta Mishra, Ronald Luwaga -Revision and editing of manuscript.

Funding source: no external funding.

Ethical approval: all procedures performed in studies involving human participants were in accordance with the ethical standards of the institutional and/or national research committee and with the 1964 Helsinki declaration and its later amendments or comparable ethical standards.

Disclosure: no potential conflict of interest relevant to this article was reported.

\section{REFERENCES}

1. Bilezikian JP, Silverberg SJ. Clinical practice. Asymptomatic primary hyperparathyroidism. N Engl J Med. 2004;350(17):1746-51.

2. Harinarayan CV, Gupta N, Kochupillai N. Vitamin D status in primary hyperparathyroidism in India. Clin Endocrinol (Oxf) 1995;43:351-8.

3. Mishra SK, Agarwal G, Kar DK, Gupta SK, Mithal A, Rastad J. Unique clinical characteristics of primary hyperparathyroidism in India. Br J Surg. 2001;88(5):708-14.

4. Arya V, Bhambri R, Godbole MM, Mithal A. Vitamin D status and its relationship with bone mineral density in healthy Asian Indians. Osteoporos Int.2004;15:56-61.

5. Muthukrishnan J, Jha S, Modi KD, Jha R, Kumar J, Verma A,et al. Symptomatic primary hyperparathyroidism: a retrospective analysis of fiftyone cases from a single centre. J Assoc Physicians India. 2008;56:503-7.

6. Bilezikian JP, Meng X, Shi Y, Silverberg SJ. Primary hyperparathyroidism in women: a tale of two cities-New York and Beijing. Int J FertilWomens Med. 2000;45(2):158-65.

7. Ohe MN, Santos RO, Barros ER, Lage A, Kunii IS, Abrahão M, et al. Changes in clinical and laboratory findings at the time of diagnosis of primary hyperparathyroidism in a University Hospital in São Paulo from 1985 to 2002. Braz J Med Biol Res. 2005;38(9):1383-7.

8. Biyabani SR, Talati J. Bone and renal stone disease in patients operated for primary hyperparathyroidism in Pakistan: is the pattern of disease different from the west? J Pak Med Assoc. 1999;49(8):194-8.

9. Gopal RA, Acharya SV, BandgarT, Menon PS, Dalvi AN, Shah NS. Clinical profile of primary hyperparathyroidism from western India: a single center experience. J Postgrad Med. 2010;56(2):79-84.

10. Yadav SK, Mishra SK, Mishra A, Mayilvagnan S, Chand G, Agarwal G, et al. Changing Profile of Primary Hyperparathyroidism Over Two and Half Decades: A Study in Tertiary Referral Center of North India. World J Surg. 2018;42(9):2732-37.

11. Younes NA, Al-Trawneh IS, Albesoul NM, Hamdan BR, Sroujieh AS. Clinical spectrum of primary hyperparathyroidism. Saudi Med J. 2003;24(2):179-83.

12. Malabu UH, Founda MA. Primary hyperparathyroidism in Saudi Arabia: a review of 46 cases. Med J Malaysia. 2007;62(5):394-7.

13. Prasarttong-Osoth $P$, Wathanaoran $P$, Imruetaicharoenchoke W, Rojananin S. Primary hyperparathyroidism: 11-year experience in a single institute in Thailand. Int J Endocrinol. 2012;2012:952426.

14. Zhao L, Liu JM, He XY, Zhao HY, Sun LH, Tao B, et al.The changing clinical patterns of primary hyperparathyroidism in Chinese 
patients: data from 2000 to 2010 in a single clinical center. J Clin Endocrinol Metab. 2013;98(2):721-8.

15. Paruk IM, Esterhuizen TM, Maharaj S, Pirie FJ, Motala AA. Characteristics, management and outcome of primary hyperparathyroidism in South Africa: a single-centre experience. Postgrad Med J. 2013;89(1057):626-31.

16. Eufrazino C, Veras A, Bandeira F. Epidemiology of Primary Hyperparathyroidism and its Non-classical Manifestations in the City of Recife, Brazil. Clin Med Insights Endocrinol Diabetes. 2013;6:69-74.

17. Shah VN, Bhadada S, Bhansali A, Behera A, Mittal BR. Changes in clinical \& biochemical presentations of primary hyperparathyroidism in India over a period of 20 years. Indian J Med Res. 2014;139(5):694-9.

18. Usta A, Alhan E, Cinel A, TürkyilmazS, Erem C. A 20-year study on 190 patients with primary hyperparathyroidism in a developing country: Turkey experience. Int Surg. 2015 Apr;100(4):648-55.

19. Jha S, Jayaraman M, Jha A, Jha R, Modi KD, Kelwadee JV. Primary hyperparathyroidism: A changing scenario in India. Indian J Endocrinol Metab. 2016;20(1):80-3.

20. Bhadada SK, Arya AK, Mukhopadhyay S, Khadgawat R, Sukumar S, LodhaS, et al. Primary hyperparathyroidism: insights from the Indian PHPT registry. J Bone Miner Metab. 2018;36(2):238-45.

21. Ahsan T, Erum U, Inam Pal KM, Jabeen R, Qureeshi SG, Rehman UL, Banu Z. The many guises of primary hyperparathyroidism: An unchanged scenario. J Pak Med Assoc. 2017 Apr; 67(4):580-5.

22. Bahrami A, Montazeri V, Barband AR, PoorzandA, Mobaseri M. Advanced Bone Diseaseas the Most Common Clinical Presentationof Primary Hyperparathyroidism in Iranians:Clinical
And Laboratory Features of62 Patients from North-Western Iran. Int JEndocrinol Metab.2006;4:19-29.

23. Bandeira F, Griz L, Caldas G, Bandeira C, Freese E. From mild to severe primary hyperparathyroidism: The Brazilian experience. Arq Bras Endocrinol Metabol. 2006;50(4):657-63.

24. Bandeira F, Griz LH, Bandeira C, Pinho J, Lucena CS, Alencar C, et al. Prevalence of cortical osteoporosis in mild and severe primary hyperparathyroidism and its relationship with bone markers and vitamin D status. J Clin Densitom. 2009;12(2):195-9.

25. Bandeira FA, Oliveira RI, Griz LH, Caldas G, Bandeira C. Differences in accuracy of $99 \mathrm{mTc}$-sestamibi scanning between severe and mild forms of primary hyperparathyroidism. $\mathrm{J} \mathrm{Nucl}$ MedTechnol. 2008 Mar;36(1):30-5.

26. Silverberg SJ, Shane E, Jacobs TP, Siris E, Bilezikian JP. A 10year prospective study of primary hyperparathyroidism with or without parathyroid surgery. N Engl J Med. 1999;341:1249-55.

27. Raue F, Jacubeit T, Minne H, Herfarth C, Ziegler R. Primary hyperparathyroidism--changes in the disease picture. Med Klin (Munich). 1989;84(4):178-82.

28. Sivula A, Ronni-Sivula $H$. The changing picture of primary hyperparathyroidism in the years 1956-1979. Ann ChirGynaecol. $1984 ; 73(6): 319-24$.

29. Heath $H$. Clinical spectrum of primary hyperparathyroidism: evolution with changes in medical practice and technology. J Bone Miner Res. 1991;6 Suppl2:S63-70; discussion S83-4.

30. Yadav SK, Mishra SK. Global Landscape of Endocrine Surgery Training Programmes and the Impact of a Structured Residency Programme in India in Development of This Subspecialty. Indian J Surg (2018). https://doi.org/10.1007/s12262-018-1833-1. 